\title{
Syntheses of $O$-Methacryloyl- $N$-Acyl Tyrosines and Their Adhesiveness to Un-etched Human Dentin
}

\author{
Jiro TANAKA, Kazuomi SUZUKI and Hiroyuki NAKAI \\ Department of Dental Materials, Okayama University Dental School, \\ 2-5-1 Shikata-cho, Okayama 700, Japan
}

Received January 31, 1994/Accepted April 15, 1994

\begin{abstract}
$O$-Methacryloyl- $N$-acyl tyrosines (MAATY) having acyl groups with the various chain length were synthesized and the strength of bonding agents, consisting of MAATY as an adhesive monomer, to unetched human dentin was studied to elucidate the relationship between the molecular structure of MAATY and its adhesive characteristics. Increasing the flexibility of the carboxyl group of tyrosine favors the interaction with the tooth substrate, causing strict bonding. Also, the properties of the neighboring carboxyl group, i. e., steric hindrance and hydrophobicity, hydrophobic-hydrophilic balance in the monomer, and shrinkage of the monomer at copolymerization, are considered important. Especially, steric hindrance of the substituted group neighboring the carboxyl group of tyrosine would play an extremely important role in the adhesion of $O$-methacryloyl- $N$-octanoyl tyrosine. The maximum tensile bond strength was obtained with a bonding agent consisting of $O$-methacryloyl- $N$-hexanoyl tyrosine $(15 \mathrm{~mol} \%)$ and hydroxyethyl methacrylate $(85 \mathrm{~mol}$ $\%)$, and the strength (4.75 $\mathrm{MPa})$ was the maximum in all methacrylates with phenylalanine as a bone structure.
\end{abstract}

Key words: Tyrosine derivative, Steric hindrance, HLB value

\section{INTRODUCTION}

All commercial bonding agents currently have extremely limited adhesive strength to unetched teeth. Therefore, etching of the enamel and dentin with acids is essential in clinical practice $^{1-3)}$. However, etching the tooth structure causes undesirable effects and if possible, should be avoided. It is therefore quite important to develop a bonding agent having favorable bonding characteristics without etching.

Suzuki et al..$^{4,5)}$ have synthesized various adhesive monomers derived from $\alpha$-amino acids, and found that $N, O$-dimethacryloyl tyrosine (DMTY), which is derived from tyrosine, has favorable adhesive characteristics to unetched human dentin. The polymer of DMTY, which is a bifunctional monomer, has a crosslinkage structure. Therefore, it is considered that the mobility of the carboxyl group, which is desirable for the formation of hydrogen and/ or coordinate bonds with tooth substrates, is restricted. Also, the neighboring structure of the carboxyl group is important. If various substitutional groups can be introduced into the amino group of tyrosine, which is in the neighborhood of the carboxyl group, it would help elucidate the favorable neighboring structure of carboxyl group received for their bonding.

$O$-Methacryloyl- $N$-acyl tyrosines (MAATY), having a methacryloyl group introduced into the position of the phenolic hydroxyl group of tyrosine and acyl groups of various chain lengths introduced into the position of amino group of tyrosine, were synthesized. Their 
adhesive properties for unetched human dentin were studied to elucidate the relationship between the molecular structure of the adhesive monomer and its bonding to unetched human dentin.

\section{MATERIALS AND METHODS}

\section{Syntheses of MAATY}

General methods for the syntheses of MAATY

MAATY were synthesized as described below.

$N$-acyl tyrosines were synthesized from L-tyrosine and various anhydrides of acids having alkyl groups corresponding to $N$-acyl groups of various chain lengths on MAATY were added under alkaline conditions $(\mathrm{pH}=9)$. MAATY were then synthesized from these $N$ -acyl tyrosines and methacryloyl chloride ( $\mathrm{MACl})$, also under alkaline conditions $(\mathrm{pH}=9 \sim 11)$ at $0 \sim 4^{\circ} \mathrm{C}$.

Syntheses of $N$-acyl tyrosines (Acylation of amino group on L-tyrosine using anhydrides) L-Tyrosine, $23 \mathrm{~g}(0.127 \mathrm{~mol})$, was placed into a $500 \mathrm{ml}$ three-necked round bottom flask equipped with a condenser and two funnels. After dissolving L-tyrosine in $240 \mathrm{ml}$ of $1 \mathrm{~N}$ $-\mathrm{NaOH}, 0.152 \mathrm{~mol}$ (1.2 times to L-tyrosine) of an anhydride (acetic, n-butyric, n-valeric, $\mathrm{n}$ -hexanoic or n-octanoic anhydrides) was added dropwise with stirring. The $\mathrm{pH}$ of the solution was maintained at $7 \sim 9$ by adding $4 \mathrm{~N}-\mathrm{NaOH}$ at the same time. After adding the anhydrides, the solution was left for $1 \mathrm{hr}$. Thereafter, $6 \mathrm{~N}-\mathrm{HCl}$ was dropped into the solution while stirring until the $\mathrm{pH}$ reached $1 \sim 2$.

In the reaction system of L-tyrosine and acetic anhydride, white crystals of $N$-acetyl tyrosine gradually precipitated in the solution. After separating the crystals, the solution was passed through filter paper. The white crystals were dried in vacuo at room temperature. Yield: $25.0 \mathrm{~g}$ ( $88 \mathrm{~mol} \%$ to L-tyrosine).

In the reaction system of $\mathrm{L}$-tyrosine and $\mathrm{n}$-butyric anhydride or $\mathrm{n}$-valeric anhydride, the reaction solution settled into two layers (oil and water phases). The two phases were collected with a separating funnel. The oil phase was washed with $1 \mathrm{~N}-\mathrm{HCl}$, and white
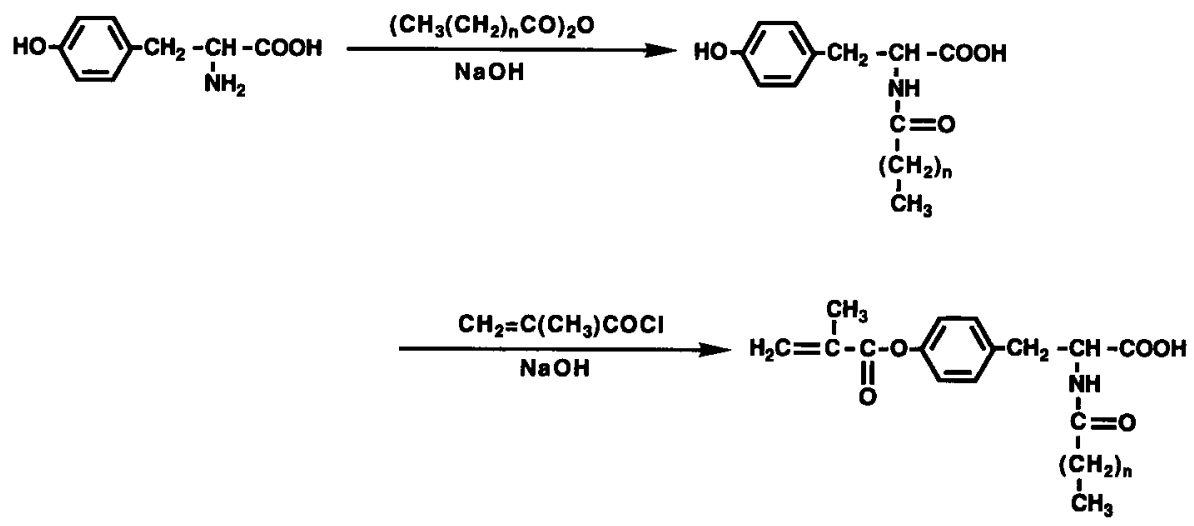

$n=0,2,3,4,6$

Scheme 1 Syntheses of $O$-methacryloyl- $N$-acyl tyrosines (MAATY) 
crystals of $N$-acyl tyrosines ( $N$-butyryl or $N$-valeryl tyrosine) gradually precipitated. After separating the crystals, the reaction solution was passed through filter paper. The white crystals were dried in vacuo at room temperature. Yield: $29.3 \mathrm{~g} N$-butyryl tyrosine (92 mol\% to L-tyrosine); $30.3 \mathrm{~g} N$-valeryl tyrosine (90 mol\% to L-tyrosine).

In the reaction system of $\mathrm{L}$-tyrosine and $\mathrm{n}$-hexanoic or $\mathrm{n}$-octanoic anhydride, the reaction solution settled into two layers. The oil and water phases were collected with a separating funnel. $N$-Acyl tyrosine ( $N$-hexanoyl and $N$-octanoyl tyrosines) was isolated by column chromatography, from the oil phase containing $N$-acyl tyrosine and the corresponding acid as co-product. The separation conditions were as follows. Packing, silica gel*; Eluent, benzene : methyl alcohol : acetic acid=48:8:8. Yield: $19.0 \mathrm{~g} N$-hexanoyl tyrosine (54 mol\% to L-tyrosine); $26.7 \mathrm{~g} N$-octanoyl tyrosine (68 mol\% to L-tyrosine).

Syntheses of MAATY (Acylation of the hydroxyl group on $N$-acyl tyrosines using $M A C l$ ) $N$-Acyl tyrosines, $0.064 \mathrm{~mol}$, were placed in a $300 \mathrm{ml}$ three-necked round bottom flask fitted with a condenser and two funnels. After dissolving $N$-acyl tyrosines in $60 \mathrm{ml}$ of $2 \mathrm{~N}-\mathrm{NaOH}$, the solution was cooled to $0 \sim 4^{\circ} \mathrm{C}$ in an ice-salt bath. Thereafter, $6.2 \mathrm{ml}$ of $\mathrm{MACl}$ was added dropwise with stirring into the solution, and the $\mathrm{pH}$ was maintained at $9 \sim 11$ by simultaneously adding $4 \mathrm{~N}-\mathrm{NaOH}$. Thereafter, the solution was left for $1 \mathrm{hr}$, then the $\mathrm{pH}$ was adjusted to about 1 using $6 \mathrm{~N}-\mathrm{HCl}$, and MAATY as white crystals precipitated. The crystals separated by filtration were recrystallized with ethyl acetate and dried in vacuo at room temperature. Yield : $12.6 \mathrm{~g}$ (68 mol\% to $N$-acetyl-L-tyrosine) $O$-methacryloyl- $N$-acetyl-L-tyrosine (MATY); $4.3 \mathrm{~g}$ (21 mol\% to $N$-butyryl-L-tyrosine) $O$-methacryloyl- $N$-butyryl-L -tyrosine (MBTY); $8.8 \mathrm{~g}$ (41 mol\% to $N$-valeryl-L-tyrosine) $O$-methacryloyl- $N$-valeryl-L -tyrosine (MVTY); $18.0 \mathrm{~g}$ (81 mol\% to $N$-hexanoyl-L-tyrosine) $O$-methacryloyl- $N$-hexanoyl-L-tyrosine (MHTY); $10.8 \mathrm{~g} \mathrm{(45} \mathrm{mol \%} \mathrm{to} N$-octanoyl-L-tyrosine) $O$-methacryloyl- $N$ -octanoyl-L-tyrosine (MOTY). These MAATY were recrystallized two or three times with ethyl acetate, and their structure and purity were determined by elementary analysis (E. A.) **, thin-layer chromatography (TLC)*, infra-red spectroscopy (IR) and nuclear magnetic resonance spectroscopy (NMR) ${ }^{\oplus}$.

\section{Preparation of bonding agents}

The bonding agent, containing MAATY, was composed of Liquids A and B. Liquid A : MAATY and hydroxyethyl methacrylate (HEMA) as a comonomer (total monomer weight $1 \mathrm{~g}$ ) were dissolved in $1 \mathrm{~g}$ of ethyl alcohol, and $10 \mathrm{mg}$ of benzoyl peroxide (BPO) as a initiator was also added. Liquid B : $10 \mathrm{mg}$ of the sodium salt of benzenesulfinic acid (BSANa) as an activator of polymerization was dissolved in $1 \mathrm{~g}$ of ethyl alcohol. An equal volume of Liquid $\mathrm{A}$ and $\mathrm{B}$ was mixed at the time of application onto the dentinal surface.

3. Preparation of specimens and the measurement of tensile bond strength

The labial surface of freshly extracted human permanent molars, stored in distilled water, was flattened with emery paper (JIS \#600), and dried in air for $10 \mathrm{~s}$. A polyethylene ring, 3.8

* Kieselgel 60, E. Merck, Darmstadt, Germany

* * MT-5, Yanako, Kyoto, Japan

\# Iatroscan TH-10 TLC/FID analyzer, Iatron laboratories, Inc., Tokyo, Japan

\# IR-810, Japan spectroscopic co., Ltd., Tokyo, Japan

(-) Varian VXR-500, Varian instruments Ltd., CA, USA 
$\mathrm{mm}$ inside diameter, was fixed on the flattened dentin surface with doublesided tape. The bonding agent containing MAATY, was applied onto the dentinal surface inside the polyethylene ring with a sponge pellet and dried in air for $15 \mathrm{~s}$. Thereafter, a composite resin was applied by its own weight. Specimens were stored in water at $37^{\circ} \mathrm{C}$ for $24 \mathrm{hr}$.

Tensile bond strength was measured by a universal testing machine $\$$ with a cross-head speed of $2 \mathrm{~mm} / \mathrm{min}$. Each experiment included 12 20 determinations. The data were evaluated by the analysis of variance and Scheffe's test for multiple comparisons between means at the $\mathrm{p}=0.05$ level of significance.

\section{Measurement of polymerization shrinkage}

MAATY, $5 \mathrm{~mol} \%$, HEMA, $95 \mathrm{~mol} \%$, and $0.2 \mathrm{wt} / \mathrm{wt} \%$ to monomer total weight of $\mathrm{BPO}$ as the initiator were placed in a polymerization ampule that was sealed with an oxygen torch under reduced pressure. Polymerization proceeded in a constant temperature water bath, electrically heated and controlled at $60 \pm 0.02^{\circ} \mathrm{C}$ for $24 \mathrm{hr}$. After complete polymerization, the monomer-initiator mixture converted to a solid of which, the shape was controlled by that of the ampule. The solid was removed from the ampule and its density was determined by directly comparing of the weight of equal volumes of solid and water at $4^{\circ} \mathrm{C}$. Polymerization shrinkage of each polymerization system of MAATY with HEMA was determined by comparing the density of polymerized solid with that of monomer mixture determined using a micropycnometer.

\section{Measurement of $p K a$}

MAATY, $0.1 \mathrm{mmol}$, were dissolved in $1 \mathrm{ml}$ of $1 \mathrm{~N}-\mathrm{NaOH}$ and each was diluted with distilled water to $20 \mathrm{ml}$. The $\mathrm{pH}$ change at the neutralization titration of the alkaline solution of MAATY with $0.3 \mathrm{~N}-\mathrm{HCl}$ was determined using $\mathrm{pH}$ meter\$. The pKa of MAATY were determined from the titration curve.

\section{RESULTS}

Elementary analyses and ${ }^{1} \mathrm{H}-\mathrm{NMR}$ spectra of MAATY and their assignments are shown in Table 1 and Fig. 1 . These results indicated that MAATY were obtained in high purity.

Table 1 Elementary analyses of $O$-methacryloyl- $N$-acyl tyrosines (MAATY)

\begin{tabular}{ccccc}
\hline MAATY & & $\mathrm{C}(\%)$ & $\mathrm{H}(\%)$ & $\mathrm{N}(\%)$ \\
\hline$O$-methacryloyl- $N$-acetyl tyrosine (MATY) & Obs'd : & 60.97 & 5.85 & 4.67 \\
& (Calc'd) : & $(61.85)$ & $(5.88)$ & $(4.81)$ \\
$O$-methacryloyl- $N$-butyryl tyrosine (MBTY) & Obs'd : & 63.42 & 6.64 & 4.39 \\
& (Calc'd) : & $(63.94)$ & $(6.63)$ & $(4.39)$ \\
$O$-methacryloyl- $N$-valeryl tyrosine (MVTY) & Obs'd : & 64.62 & 6.98 & 4.19 \\
& (Calc'd) : & $(65.05)$ & $(6.67)$ & $(4.21)$ \\
$O$-methacryloyl- $N$-hexanoyl tyrosine (MHTY) & Obs'd: & 65.28 & 7.28 & 4.00 \\
& (Calc'd) : & $(65.69)$ & $(7.25)$ & $(4.03)$ \\
$O$-methacryloyl- $N$-octanoyl tyrosine (MOTY) & Obs'd : & 67.23 & 7.86 & 3.67 \\
& (Calc'd) : & $(67.18)$ & $(7.78)$ & $(3.73)$ \\
\hline
\end{tabular}

(a) Clearfil F-II, Kuraray, Okayama, Japan

$\$$ Autograph DCS-2000, Shimadzu Corp., Kyoto, Japan

$\$ \$$ F-8DP, Horiba, Kyoto, Japan 
The tensile bond strength of MAATY-hydroxyethyl methacrylate (HEMA) bonding systems to the unetched human dentin $(\# 600)$ is shown in Table 2. The monomer feed of MAATY had an apparent influence on the tensile bond strength. The optimum of all MAATY-HEMA bonding systems except $O$-methacryloyl- $N$-acetyl tyrosine (MATY), which was very slightly soluble in HEMA, appeared unrelated to the chain length of the $N$ -acyl group in MAATY, at about $15 \mathrm{~mol} \%$ in the monomer feed. The optimum tensile bond

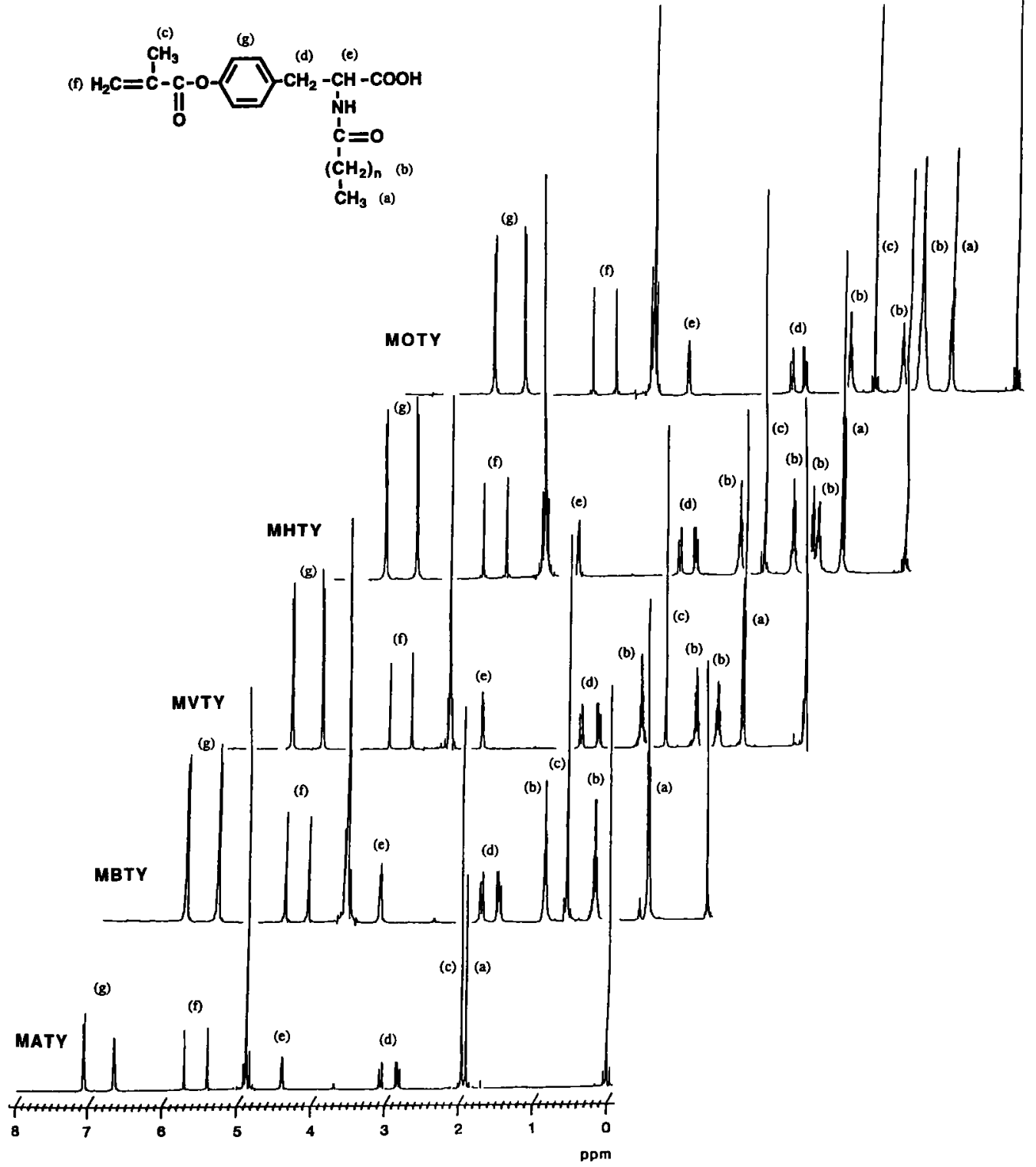

Fig. $1{ }^{1} \mathrm{H}-\mathrm{NMR}$ spectra of MAATY at $500 \mathrm{MHz}$ in $\mathrm{D}_{2} \mathrm{O}+\mathrm{NaOD}$ at room temperature. 
strength of each MAATY-HEMA complex tended to become stronger with increasing carbon numbers in the $N$-acyl group of MAATY. The complex of $O$-methacryloyl- $N$ -hexanoyl tyrosine (MHTY; the carbon number of $N$-acyl group, $\mathrm{n}=6$ ) with HEMA peaked and showed maximal tensile bond strength in all MAATY-HEMA systems. The tensile strength decreased in $O$-methacryloyl- $N$-octanoyl tyrosine (MOTY; $\mathrm{n}=8$ ), which has a longer acyl chain. The optimal tensile bond strength of the MOTY-HEMA system was weaker than those of $O$-methacryloyl- $N$-butyryl tyrosine (MBTY; $\mathrm{n}=4$ ), $O$-methacryloyl $-N$-valeryl tyrosine (MVTY; $\mathrm{n}=5)$ and MHTY $(\mathrm{n}=6)$.

The polymerization shrinkage of each copolymerization system determined based upon the bulk copolymerization of MAATY ( $5 \mathrm{~mol} \%$ ) with HEMA (95 mol\%) and pKa of carboxyl group on MAATY, was plotted against the carbon number of the $N$-acyl chain of MAATY as shown in Fig. 2. The shrinkage of each copolymerization system tended to decrease with the increasing carbon number of the $N$-acyl chain. On the other hand, the pKa of the

Table 2 The effect of the molar ratio of MAATY in MAATY-HEMA bonding systems on the adhesive strength to unetched human dentin $(\# 600)$

\begin{tabular}{|c|c|c|c|c|c|}
\hline \multirow{3}{*}{$\begin{array}{l}\text { Molar ratio } \\
\text { of MAATY }\end{array}$} & \multicolumn{5}{|c|}{ Tensile bond strength ( $\mathrm{MPa}$ ) } \\
\hline & \multicolumn{5}{|c|}{ MAATY } \\
\hline & MATY & MBTY & MVTY & MHTY & MOTY \\
\hline 0 & $0.92(0.61)$ & $0.92(0.61)$ & $0.92(0.61)$ & $0.92(0.61)$ & $0.92(0.61)$ \\
\hline 0.05 & $1.39(0.95)$ & $1.52(0.57)$ & $2.48(1.55)$ & $2.06(1.35)$ & $2.30(0.70)$ \\
\hline 0.10 & & $2.35(0.45)$ & $3.04(1.34)$ & $3.45(1.37)$ & $3.28(0.66)$ \\
\hline 0.13 & & $3.80(0.44)$ & $3.63(1.29)$ & $3.60(0.96)$ & $3.44(1.00)$ \\
\hline 0.15 & & $4.16(0.69)$ & $3.84(1.66)$ & $4.75(1.68)$ & $3.51(0.83)$ \\
\hline 0.17 & & $3.36(0.79)$ & $3.46(1.22)$ & $4.68(1.25)$ & $3.46(0.92)$ \\
\hline 0.20 & & $2.79(1.01)$ & $2.85(0.78)$ & $3.17(1.23)$ & $3.28(1.57)$ \\
\hline
\end{tabular}

$\mathrm{n}=12 \sim 20, \mathrm{SD}$ in parentheses

Means connected by bars were not significantly different.

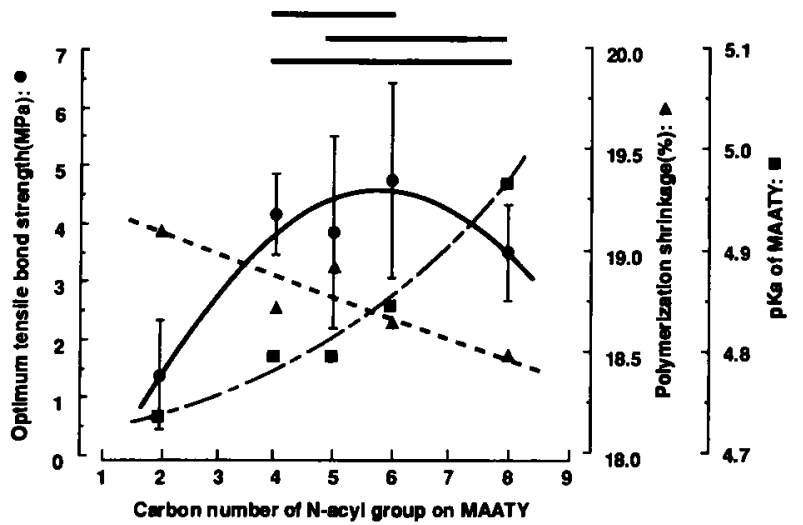

Fig. 2 Relationship between the adhesive strength, shrinkage at copolymerization, pKa of MAATY and the carbon number of the $N$-acyl group in MAATY. Means connected by bars were not significantly different on the bond strength. 
carboxyl group on MAATY tended to increase tendency with increasing carbon atoms of the $N$-acyl chain.

\section{DISCUSSION}

The tensile bond strength of each MAATY-HEMA system to unetched human dentin (\#600) was more sensitive to the monomer feed ratio than DMTY-HEMA system ${ }^{4}$. The former consisted of tyrosine and it was bifunctional with regard to the polymerizing factor, with HEMA as showing in Table 2. The optimal tensile bond strength on each MAATY-HEMA system was $15 \mathrm{~mol} \%$ in the monomer feed of MAATY. This was similar to the optimum monomer feed composition in the majority of adhesive monomers, which continued monofunctional monomers for polymerization, which is in the neighborhood of $5 \sim 10 \mathrm{~mol} \% .^{6 \sim 8)}$ On the other hand, the optimum tensile bond strength of copolymerization systems of a series of methacrylates, consisting of tyrosine with HEMA, was $30 \mathrm{~mol} \%$ in the monomer feed of the methacrylates. ${ }^{4,5)}$

There are four influences of the introduced acyl groups with various chain lengths, on the amino group in the neighborhood of the carboxyl group of tyrosine in MAATY, on the tensile bond strength of MAATY-HEMA and unetched human dentin. That is, increasing hydrophobicity, steric hindrance of the carboxyl group, affecting its $\mathrm{pKa}$ and decreasing the polymerization shrinkage. Thus the optimum tensile bond strength of MAATY-HEMA systems to unetched human dentin tended to become greater with increasing the carbon number of the $N$-acyl group. The MHTY (n=6)-HEMA system showed a peak, which was smaller in that of MOTY $(n=8)$ with a longer acyl chain, as shown in Fig. 2. The hydrophobicity index of the $N$-acyl groups is represented by the carbon number, so it increased following the increase of the carbon number in the order: MATY $<$ MBTY $<$ MVTY $<$ MHTY $<$ MOTY. Therefore, the tendency of the optimum tensile bond strength of MAATY -HEMA bonding systems cannot be determined only from the hydrophobicity of $N$-acyl groups. The pKa of the carboxyl group on MAATY increases and polymerization shrinkage of MAATY-HEMA system decreases following an increase in the carbon number of the $N$ -acyl group as shown in Fig. 2. The increasing pKa and decreasing polymerization shrinkage are convenient for adhesion to dentin. The tendency of an MAATY, except MOTY, can be determined by the $\mathrm{pKa}$ and polymerization shrinkage. However, MOTY-HEMA bonding system have low adhesive strength despite their favorable pKa and low polymerization shrinkage.

Kawaguchi et al.$^{9)}$ calculated using Hydrophile-lipophile balance (HLB) numbers ${ }^{10,11)}$ the relationship among several monomers for evaluating the effect of the hydrophilic and hydrophobic group of the monomer with a carboxyl group as a functional group in the adhesive bonding to unetched dentin. The results indicated that the adhesive strength was highest when the HLB number of the adhesive monomer was near 7 ; that is, the hydrophobic and hydrophilic properties were equivalent. Thus, the HLB numbers of MAATY were calculated according to Griffin's equation ${ }^{11}$, and the relationship between the optimum tensile bond strength of MAATY-HEMA systems and the HLB numbers of MAATY are shown in Fig. 3. MAATY, except for MOTY, functioned in the same manner as described by 
Kawaguchi et al.9). The closer the HLB numbers of MAATY to 7, the higher the optimum tensile bond strength of MAATY-HEMA system. MOTY had low adhesive strength although its the HLB number is near 7 .

These results suggest that there are several causes of the low adhesive strength of the MOTY-HEMA system. The increasing steric hindrance of the $N$-acyl groups following the increasing carbon numbers of $N$-acyl groups should be considered. Regarding bonding agents consisting of methacrylates containing tyrosine, $\mathrm{N}, \mathrm{O}$-dimethacryloxy tyrosine ethyl ester as an adhesive monomer scarcely adhered to the unetched tooth substance ${ }^{5}$. This shows that the adhesion of a bonding agent consisting of MAATY to the tooth substance, is mainly due to the hydrogen bond formed between the carboxyl group on MAATY and the tooth surface. As described above, increasing the carbon number of the $N$-acyl group means increasing the steric hindrance to the carboxyl group, which plays the leading role in adhesion between the adhesive monomer and the tooth substance. It is assumed that the steric hindrance of $N$-octanoyl group $(\mathrm{n}=8)$ contrasts in a striking way with that of $N$ -hexanoyl group $(n=6)$ to the carboxyl group. To confirm this assumption, molecular structures in space filling and wire frame molecular models of MAATY in which the steric hindrance of the $N$-acyl group (the red solid line in molecular model) to the carboxyl group (the blue solid line) is the largest, were assembled by a molecular modelling program ${ }^{+}$(Fig. 4). $N$-Acyl groups of $\mathrm{n}=6$ and below, namely, $N$-acetyl, $N$-butyryl, $N$-valeryl and $N$

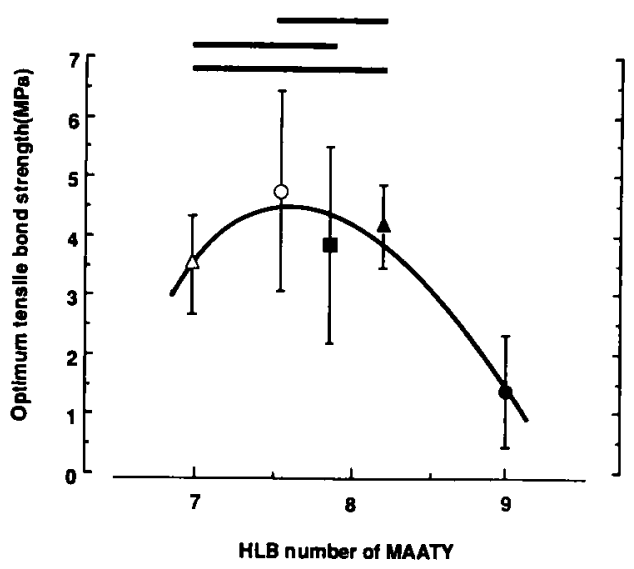

Fig. 3 The relationship between the HLB values of MAATY and the optimum tensile bond strength of MAATY-HEMA systems to the unetched human dentin. Means connected by bars were not significantly different.
- MATY (5)-HEMA
A : MBTY (15)-HEMA
口: MVTY (15)-HEMA
$O$ : MHTY (15)-HEMA
$\triangle:$ MOTY (15)-HEMA

+ Chem 3 DPlus Ver. 3, Cambridge Scientific Computing, Inc., MA, USA 


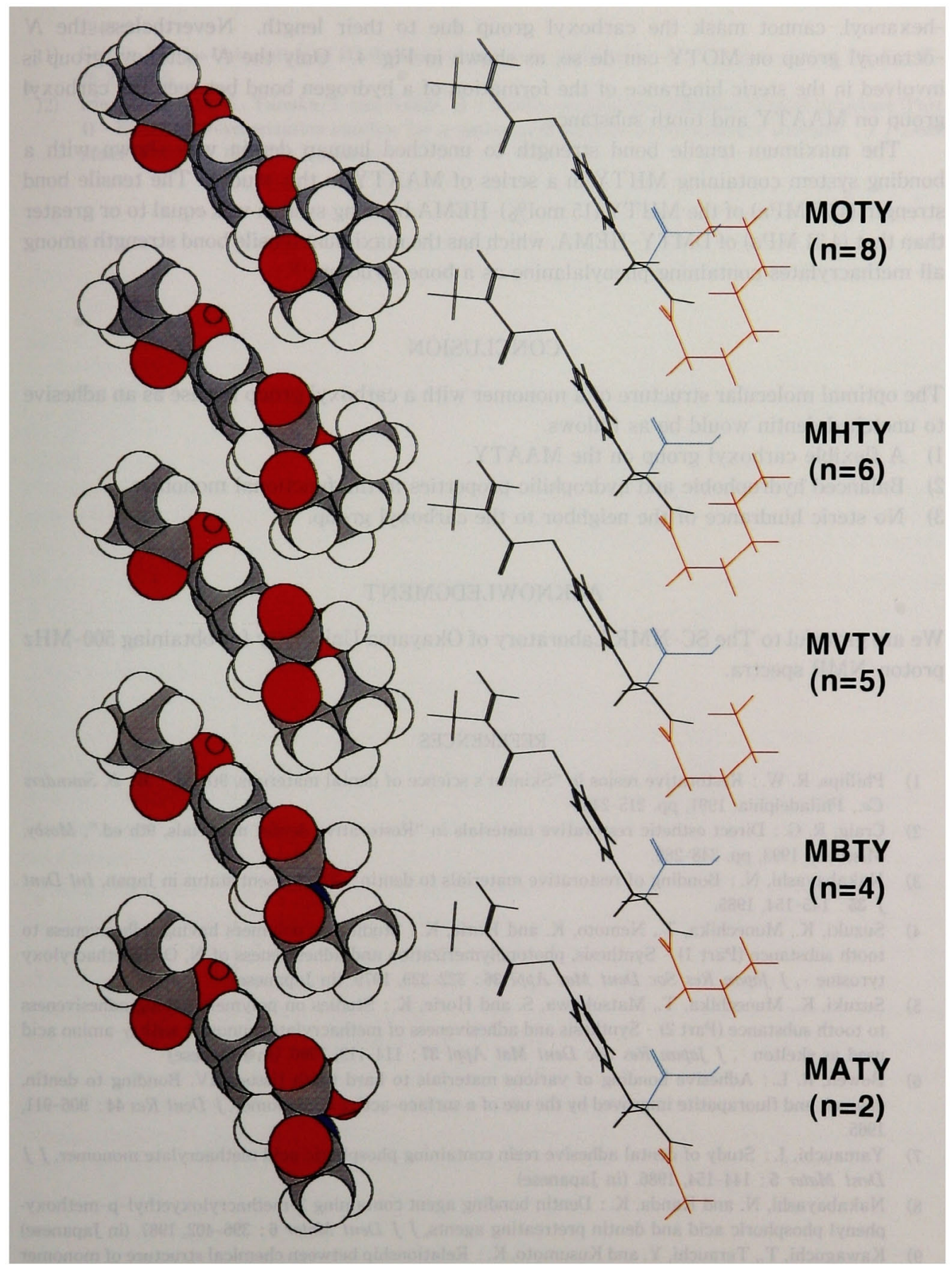

Fig. 4 A three-dimensional demonstration of the steric hindrance of the $N$-acyl group on MAATY to the carboxyl group. 
-hexanoyl, cannot mask the carboxyl group due to their length. Nevertheless, the $N$ -octanoyl group on MOTY can do so, as shown in Fig. 4. Only the $N$-octanoyl group is involved in the steric hindrance of the formation of a hydrogen bond between the carboxyl group on MAATY and tooth substance.

The maximum tensile bond strength to unetched human dentin was shown with a bonding system containing MHTY in a series of MAATY in this study. The tensile bond strength (4.75 MPa) of the MHTY (15 mol\%)-HEMA bonding system was equal to or greater than that (4.31 MPa) of DMTY-HEMA, which has the maximum tensile bond strength among all methacrylates containing phenylalanine as a bone structure ${ }^{12)}$.

\section{CONCLUSION}

The optimal molecular structure of a monomer with a carboxyl group for use as an adhesive to unetched dentin would be as follows.

1) A flexible carboxyl group on the MAATY,

2) Balanced hydrophobic and hydrophilic properties in the functional monomer,

3) No steric hindrance of the neighbor to the carboxyl group.

\section{ACKNOWLEDGMENT}

We are grateful to The SC-NMR Laboratory of Okayama University for obtaining $500-\mathrm{MHz}$ proton-NMR spectra.

\section{REFERENCES}

1) Phillips, R. W. : Restorative resins in "Skinner's science of dental materials, 9th ed.", W. B. Saunders Co., Philadelphia, 1991, pp. 215-248.

2) Craig, R. G. : Direct esthetic restorative materials in "Restorative dental materials, 9th ed.", Mosby, Missouri, 1993, pp. 248-282.

3) Nakabayashi, N.: Bonding of restorative materials to dentin: The present status in Japan, Int Dent J 35 : 145-154, 1985.

4) Suzuki, K., Munechika, T., Nemoto, K. and Horie, K.: Studies on polymers having adhesiveness to tooth substance (Part 1) - Synthesis, photopolymerization and adhesiveness of N, O-dimethacryloxy tyrosine -, J Japan Res Soc Dent Mat Appl $36: 322-329$, 1979. (in Japanese)

5) Suzuki, K., Munechika, T., Matsukawa, S. and Horie, K.: Studies on polymers having adhesiveness to tooth substance (Part 2) - Synthesis and adhesiveness of methacrylate monomer with $\alpha$-amino acid used as skelton -, J Japan Res Soc Dent Mat Appl 37 : 114-119, 1980. (in Japanese)

6) Bowen, R. L. : Adhesive bonding of various materials to hard tooth tissues. IV. Bonding to dentin, enamel, and fluorapatite improved by the use of a surface-active comonomer, $J$ Dent Res 44 : 906-911, 1965.

7) Yamauchi, J.: Study of dental adhesive resin containing phosphoric acid methacrylate monomer, $J J$ Dent Mater 5 : 144-154, 1986. (in Japanese)

8) Nakabayashi, N. and Kanda, K. : Dentin bonding agent containing 2-methacryloxyethyl-p-methoxyphenyl phosphoric acid and dentin pretreating agents, $J J$ Dent Mater 6 : 396-402, 1987. (in Japanese)

9) Kawaguchi, T., Terauchi, Y. and Kusumoto, K. : Relationship between chemical structure of monomer and adhesive strength, $J$ Dent Res $69: 231,1990$.

10) Griffin, W. C. : Classification of surface-active agents by "HLB", J Soc Cosmetic Chemists 1: 311-326, 
1946.

11) Griffin, W. C. : Calculation of HLB values of non-ionic surfactants, Am Perfumer Essent Oil Rev 65 : 26-29, 1955.

12) Irie, M., Suzuki, K., Tanaka, J. and Nakai, H. : Studies on polymers adhesive to tooth structure (Part 4) - Effect of polymerization catalyst for $\alpha$-amino acid acrylate on the adhesive strength,$- J J$ Dent Mater $4:$ 92-96, 1985. (in Japanese) 
2 種の結晶を含有するキャスタブルガラス

セラミックスの機械的強さに及ほすす結晶化の影響

今 政幸, 河野文昭 ${ }^{1}$, 多田芳雄 ${ }^{1}$, 井上三四郎 ${ }^{1}$

浅岡憲三，松本直之 ${ }^{1}$

徳島大学歯学部歯科理工学绕座

'徳島大学歯学部歯科補緅学第一講座

アパタイトとチタン酸マグネシウムの 2 種の結晶が析 出するキャスタフルガラスセラミックスの機械的性質に 及浪す結晶化（セラミング）の影整を検討するため，結 晶化処理温度を変化させ，曲げ強さ，破填靱性および硬 さなどを調へた。その結果，結晶化処理したガラスセラ ミックスの曲げ強さは結晶相の增加につれて高くなるこ とがわかった. ガラスセラミックス中に析出するチタン 酸マグネシウムは同量のアパタイトの析出に比較し, 強
さに対して効果的であることが示唆された。破壊䩓性は アパタイト結晶だけを析出させた試験片で,アスキャス トの場合に比較して，2倍の值が得られた.このことは 硬さの低いアパタイト粒子でもクラックのピン止め効果 を持つものと考えられた。本材料は市販のボティー用陶 材より高い機械的性質が得られたことから，畫美補綴材 料として使用できる可能性が示唆された。

\section{O-メタクリロイル-N-アシルチロシンの合成と無処理人歯象牙質に対する接着性 田仲持郎, 鈴木一臣, 中井宏之 \\ 岡山大学雬学部菌科理工学譳座}

接着性モノマーの分子構造と接着性との相関を調べる ことを目的として,種々の長さのアシル鎖を持つの-メタ クリロイル-N-アシルチロシン (MAATY) を合成, そ れらを含むボンディング绪を調製し，その無処理人蒾象 牙質に対する接着強さについて検討した。そその結果は, チロシン骨格のカルボキシル基の自由度の増大が歯質と の相互作用にとって好ましく強固な接着の要因であると 考えられた，又，立体障害，疎水性といったカルボキシ ル基近傍の棈造, モノマー分子の疎水性一䚇水性のバラ
ンス, 共重合系の重合収縮が重要であることが示唆され た。特に,カルボキシル基の隣接基の立体障害が O-メタ クリロイル-N-オクタノイルチロシンの場合には極めて

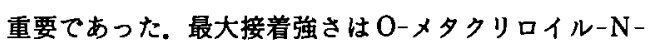
ヘキサノイルチロシン (15 mol \%)-HEMA (85 mol \%) から成るボンディング剤で得られ，その接着強さ(4.75 $\mathrm{MPa})$ はフェニルアラニンを骨格に持つメタクリレート のうちで最大であった.

リン酸で処理した象牙質への接着における銅イオン含有プライマーの効果 今井庸二, 池村竜一郎

東京医科齿科大学医用器材研究所

象牙質界面での重合を促進することが可能な銅イオン を合むプライマーについて検討した，牛雨象牙質表面を $10 \%$ リ酸水溶莈で前処理した後, $0.03 \%$ 銅程を含

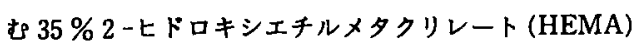

水溶液からなるプライマーを泭布し，4-META/MMATBBO レジンで接着した. このプライマーを用いること により,プライマーを用いないときの接着強さ 3.8 $\mathrm{MPa}$, あるいは銅塩を含まない $35 \%$ HEMA プライマ 